\title{
REAKCJA WÓD POWIERZCHNIOWYCH I PODZIEMNYCH NA OPADY W ZLEWNI RÓŻANEGO STRUMIENIA
}

\author{
ALEKSANDRA CZUCHAJ, *FILIP WOLNY,**MAREK MARCINIAK \\ Wydział Nauk Geograficznych i Geologicznych, \\ Uniwersytet im. Adama Mickiewicza w Poznaniu, ul. B. Krygowskiego 10, 61-680 Poznań \\ *ORCID: 0000-0002-5377-5585, **ORCID: 0000-0002-5377-5585
}

\begin{abstract}
The aim of the presented research was to analyze the relation between three variables: the daily sum of precipitation, the surface water level and the groundwater level in the Różany Strumień basin located in Poznań, Poland. The correlation coefficient for the subsequent lags for each pair of variables time series has been calculated. The delay with which waters of the basin respond to precipitation varies significantly. Generally, stronger response to rainfall is observed for surface water levels as opposed to groundwater levels.
\end{abstract}

Keywords: rainfall-runoff, basin lag, basin monitoring, water table fluctuations

\section{WSTĘP}

W badaniach przyrodniczych, których celem jest szczegółowa charakterystyka obiegu wody w zlewni istotną rolę odgrywa właściwe rozpoznanie relacji między opadem a odpływem. Jednym z parametrów opisujących tę relację jest czas opóźnienia odpływu, parametr znany w literaturze anglojęzycznej pod nazwą basin lag lub basin lag time. Najogólniej można go zdefiniować jako średni czas, w którym woda pochodząca z opadu atmosferycznego pozostaje w obrębie zlewni. W wielu badaniach wyznaczany jest jako czas między środkiem ciężkości hietogramu opadu efektywnego a hydrogramu odpływu bezpośredniego (McCuen i in. 1984; Granato 2012; Krajewski, Banasik 2013). Przy takim podejściu często pomija się badanie reakcji wód podziemnych na opad, podczas gdy infiltracja opadu zwykle stanowi główne źródło zasilania płytkich warstw wodonośnych (Healy 2010; Graf, Kajewski 2013; Qi i in. 2018).

Przedmiotem pracy jest analiza relacji między trzema zmiennymi: opadem atmosferycznym, natężeniem przepływu wód powierzchniowych oraz stanami wód podziemnych w obrębie zlewni Różanego Strumienia. Analiza ma na celu określenie czasu reakcji wód powierzchniowych i podziemnych na opad. 


\section{OBSZAR BADAŃ}

Zlewnia Różanego Strumienia, o powierzchni 7,7 km², położona jest w północnej części Poznania. Zgodnie z podziałem Polski na regiony fizycznogeograficzne (Kondracki 2009) znajduje się na granicy dwóch mezoregionów - Pojezierza Poznańskiego i Poznańskiego Przełomu Warty. Obszar zlewni poddany jest silnej antropopresji. Południowa granica zlewni wyznaczona jest przez przebieg magistrali kolejowej. Ponadto w zlewni znajdują się osiedla mieszkaniowe oraz kampus UAM Morasko, a w jej północnej części usytuowane zostały zbiorniki wyrównawcze poznańskiego systemu wodociągowego administrowanego przez przedsiębiorstwo Aquanet. Źródła strumienia o długości około 6 km znajdują się na Górze Moraskiej (154 m n.p.m.). Ciek uchodzi do Warty na wysokości około 50 m n.p.m. Zlewnia Różanego Strumienia cechuje się zatem znaczną deniwelacją terenu. W jej obrębie występują trzy główne formy rzeźby terenu ciąg pagórów czołowomorenowych, wysoczyzna morenowa falista oraz równina sandrowa (Sandr Naramowicki). W głównej mierze zlewnię pokrywają piaski i żwiry oraz gliny morenowe - osady morenowe zalegają do głębokości około $20 \mathrm{~m}$. W dolinie strumienia występują także osady fluwialne (Major i in. 2016). Jako bezpośredni obszar badań wybrano centralny fragment zlewni, tj. obszar Stacji Bazowej ZMŚP „Poznań-Morasko”, w otoczeniu strumienia. Na odcinku, w którym znajduje się stanowisko pomiarowe, obserwuje się infiltrację wód cieku do warstwy wodonośnej.

Zgodnie z podziałem Polski na regiony klimatyczne (Woś 1993) zlewnia Różanego Strumienia zlokalizowana jest $w$ regionie środkowopolskim. Ze względu na nieostre granice, brak skrajnych liczby dni o określonym typie pogody w stosunku do sąsiednich regionów. Roczna suma opadów na Stacji Bazowej ZMŚP w 2017 r. wyniosła 741,4 mm, a w 2018 r. 425,0 mm.

W zlewni zwierciadło wód gruntowych występuje na głębokości 2-7 m p.p.t. Zasadniczym źródłem zasilania tych wód jest infiltracja opadów atmosferycznych. W okolicy Wydziału Nauk Geograficznych i Geologicznych do głębokości około $10 \mathrm{~m}$ zalegają głównie piaski drobne i pylaste, z licznymi przewarstwieniami i wkładkami pyłów, oraz piaski gliniaste, gliny pylaste, a także piaski średnio- i różnoziarniste. W spągu warstwy wodonośnej odnotowuje się gliny fazy poznańskiej zlodowacenia bałtyckiego (Okońska, Wolny 2011).

Stacja bazowa ZMŚP znajduje się przy Wydziale Nauk Geograficznych i Geologicznych Uniwersytetu im. Adama Mickiewicza w Poznaniu - jest ona częścią sieci Zintegrowanego Monitoringu Środowiska Przyrodniczego (ryc. 1). Obejmuje m.in. ogródek meteorologiczny z deszczomierzem Hellmanna, sieć kilkunastu piezometrów do obserwacji stanów wód podziemnych, a także koryto Parshalla, zamontowane w Różanym Strumieniu, służące do odczytu stanu wód Różanego Strumienia oraz określania natężenia przepływu. 


\section{DANE POMIAROWE I METODYKA BADAWCZA}

Badanie zależności między trzema charakterystykami - opadem, natężeniem przepływu wód powierzchniowych oraz stanem wód podziemnych - przeprowadzono dla roku hydrologicznego 2017 (roku bardzo wilgotnego) oraz 2018 (roku suchego), na podstawie dobowych serii obserwacyjnych.

Suma dobowych opadów atmosferycznych była określana przez obserwatora za pomocą deszczomierza Hellmanna o godzinie 7:00 czasu UTC+1:00. Urządzenie to znajduje się w ogródku meteorologicznym w sąsiedztwie budynków Wydziału Nauk Geograficznych i Geologicznych UAM (ryc. 1).

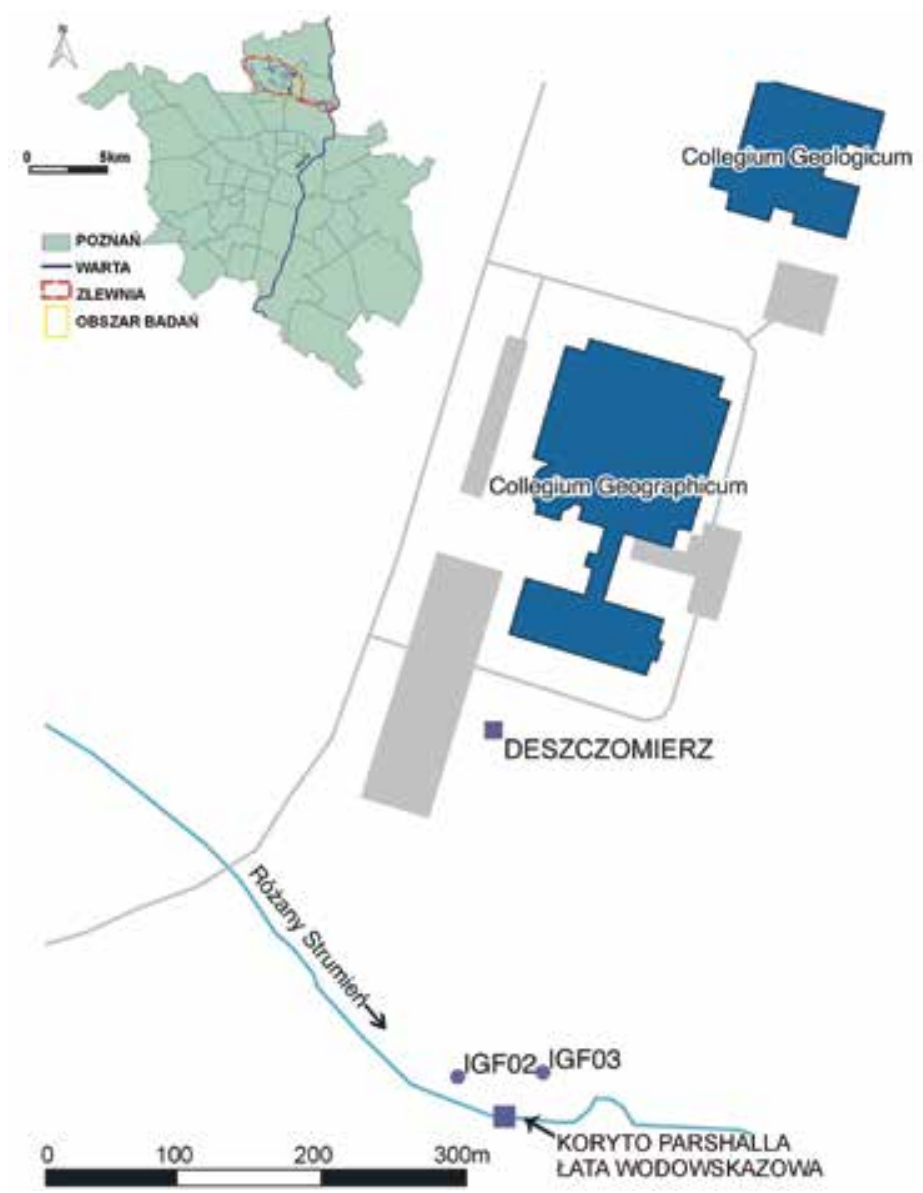

Ryc. 1. Obszar badań z zaznaczoną lokalizacją deszczomierza, punktu pomiaru natężenia przepływu wód w Różanym Strumieniu oraz piezometrów IGF02 i IGF03

Fig. 1. Map of the study area depicting the rain gauge, the water flow measuring point and the observation wells IGF02 and IGF03 
Stan wód oraz natężenie przepływu w Różanym Strumieniu były odczytywane raz na dobę, również o godzinie 7:00. Do obliczenia natężenia przepływu wykorzystywano krzywą przepływu wyznaczoną przez producenta koryta Parshalla, wiążącą przepływ ze stanami wody.

Pomiary położenia zwierciadła wód podziemnych w otworach hydrogeologicznych rejestrowano przez datalogger typu diver w każdej dobie o godzinie 7:00. Do celów badawczych wybrano piezometry IGF02 i IGF03 zlokalizowane na lewym brzegu cieku, w odległościach odpowiednio: około 15 i około $30 \mathrm{~m}$.

Czas reakcji zlewni Różanego Strumienia na opad atmosferyczny określono, obliczając wartości współczynnika korelacji liniowej Pearsona (R) dla następujących kombinacji zmiennych:

1. opadu i natężenia przepływu wód powierzchniowych,

2. opadu i stanów wód podziemnych.

Ponadto, z uwagi na infiltrujący charakter cieku, obliczono wartości współczynnika korelacji liniowej Pearsona (R) dla:

3. natężenia przepływu wód powierzchniowych i stanów wód podziemnych.

Wartości współczynnika korelacji wyznaczono dla każdego roku hydrologicznego, a także dla poszczególnych miesięcy roku hydrologicznego.

Przy określaniu czasu reakcji natężenia przepływu wód powierzchniowych na opad atmosferyczny obliczono współczynnik korelacji dla miesięcznego zakresu danych. Następnie przesuwano miesięczny zakres danych dotyczących stanów wód powierzchniowych o kolejne doby, pozostawiając zakres czasowy analizowanego opadu bez zmian. Za czas reakcji natężenia przepływu wód powierzchniowych na opad atmosferyczny przyjęto czas, dla którego uzyskano najwyższą wartość współczynnika korelacji. Podobnie określono czas reakcji dla dwóch pozostałych kombinacji zmiennych.

\section{WYNIKI BADAŃ}

\section{Charakterystyka opadów atmosferycznych}

Średni wieloletni opad dla Poznania wynosi $520 \mathrm{~mm}$ według danych IMGW z posterunku Poznań-Ławica. W badanym okresie rok 2017 charakteryzował się roczną sumą opadów atmosferycznych wynoszącą 741,4 mm, a w roku 2018 suma ta wyniosła 425,0 mm. Zgodnie z klasyfikacją warunków wilgotnościowych Kaczorowskiej (1962) rok 2017 należy uznać za bardzo wilgotny (142\% przeciętnej sumy wieloletniej opadu), natomiast rok 2018 za rok suchy (81\% przeciętnej sumy z wielolecia).

W roku bardzo wilgotnym (2017) najniższym opadem cechował się styczeń (21,6 mm), najwyższym zaś lipiec $(152,5 \mathrm{~mm})$. Miesiące zimowo-wiosenne 
odznaczały się niezbyt wysokimi opadami w skali roku - zdecydowanie większe opady wystąpiły w okresie letnio-jesiennym (ryc. 2).

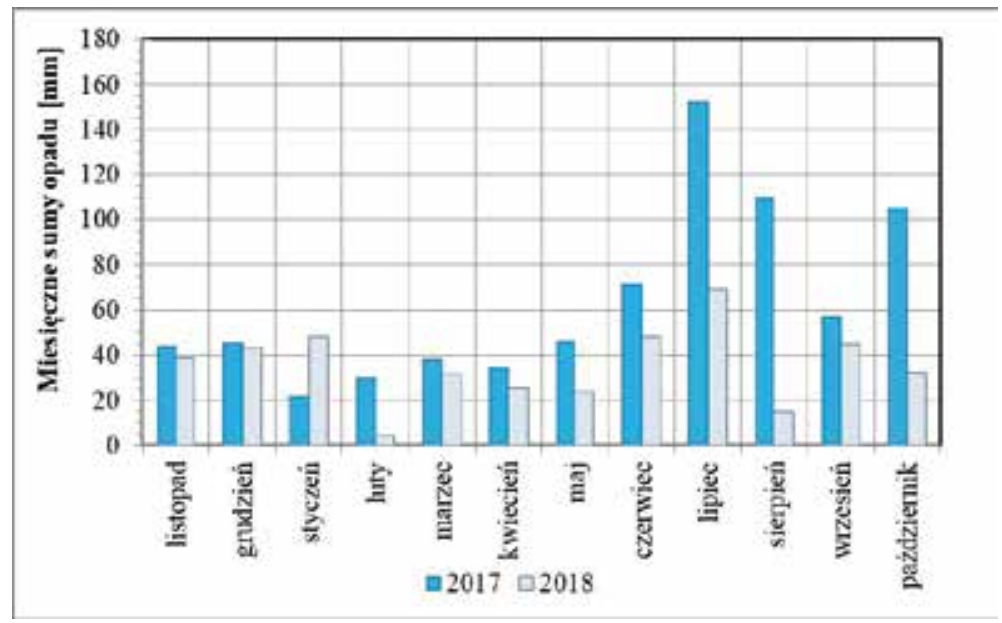

Ryc. 2. Miesięczne sumy opadów atmosferycznych w latach hydrologicznych 2017 i 2018 w zlewni Różanego Strumienia

Fig. 2. Total monthly precipitation in hydrological years 2017 and 2018 in the Różany Strumień basin

Letnia kulminacja opadowa miała miejsce także w roku suchym. Jednakże lipiec 2018 r. charakteryzował się sumą opadów dwukrotnie niższą niż ten sam miesiąc w roku 2017. Poza lipcem miesięczna suma opadów ani razu nie przekroczyła $50 \mathrm{~mm}$. Minimum zaobserwowano w lutym, opad wyniósł wówczas zaledwie 4,3 mm. Bardzo suchym miesiącem był także sierpień 2018 r. $14,8 \mathrm{~mm}$.

\section{Charakterystyka natężenia przepływu różanego strumienia}

Przepływy obserwowane w Różanym Strumieniu w roku hydrologicznym 2017 charakteryzują się wyższymi wartościami w okresie letnio-jesiennym aniżeli zimowo-wiosennym. Od listopada 2016 r. do końca lutego 2017 r. przepływy w większości nie przekraczały $30 \mathrm{dm}^{3} \times \mathrm{s}^{-1}$. W ciągu kolejnych miesięcy przepływy nie spadały poniżej $10 \mathrm{dm}^{3} \times \mathrm{s}^{-1}$, nie przekraczając $50 \mathrm{dm}^{3} \times \mathrm{s}^{-1}$. Spadek ich wielkości, przy jednoczesnym zagęszczeniu występowania gwałtownych wezbrań, można było zaobserwować od końca maja, a od połowy lipca miał miejsce kolejny wzrost. Po sierpniowych maksimach nastąpiło obniżenie się przepływów we wrześniu, jednakże w końcówce października ponownie odnotowano tendencję rosnącą (ryc. 3). 


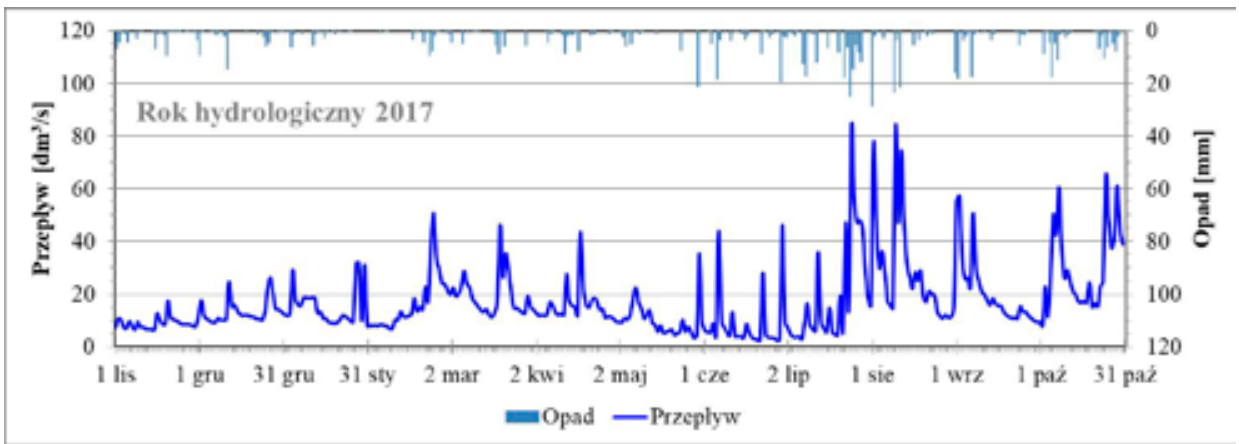

Ryc. 3. Przepływy dobowe zmierzone w Różanym Strumieniu w roku hydrologicznym 2017

Fig. 3. Daily discharge of the Różany Strumień at the measuring point in hydrological year 2017

Rok hydrologiczny 2018 rozpoczął się maksymalnym przepływem $73 \mathrm{dm}^{3} \times \mathrm{s}^{-1} \mathrm{w}$ dniu 2 listopada $2017 \mathrm{r}$. Następnie przepływy malały i nie przekroczyły już ani razu $60 \mathrm{dm}^{3} \times \mathrm{s}^{-1}$. W okresie wiosennym przepływy regularnie malały aż do 22 czerwca, kiedy po raz pierwszy nie zanotowano przepływu na analizowanym odcinku Strumienia Różanego. Kolejnym okresem z suchym korytem był 4-11 lipca 2018 r. Po tym okresie w Różanym Strumieniu ponownie stwierdzono przepływ wody. Na początku sierpnia rozpoczął się kolejny okres, kiedy w korycie nie obserwowano przepływu wody. Pojawia się on ponownie pod koniec września (ryc. 4).

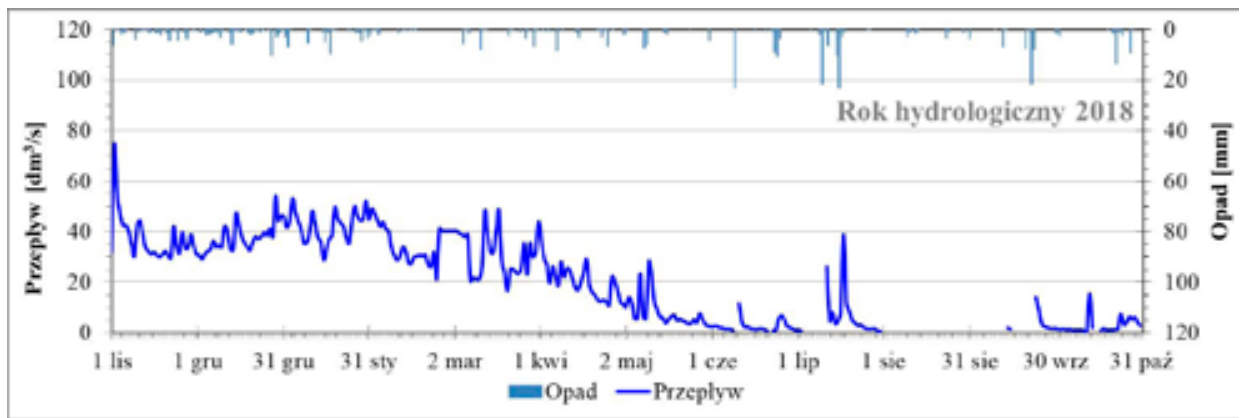

Ryc. 4. Przepływy dobowe zmierzone w Różanym Strumieniu w roku hydrologicznym 2018 Fig. 4. Daily discharge of the Różany Strumień at the measuring point in hydrological year 2018

\section{Charakterystyka stanów wód podziemnych}

W bardzo wilgotnym roku hydrologicznym 2017 zauważa się tendencję wzrostową poziomu zwierciadła $\mathrm{w}$ obu piezometrach. Poziom wody w piezometrze IGF02 1 listopada 2016 r. wynosił $106 \mathrm{~cm}$, a 31 października $2017 \mathrm{r}$. 
$147,8 \mathrm{~cm}$ (ryc. 5). Analogiczną tendencję zaobserwowano w piezometrze IGF03 $-72,4 \mathrm{~cm}$ na początku roku hydrologicznego i $104,3 \mathrm{~cm}$ pod jego koniec. Można zatem stwierdzić, że warstwa wodonośna reagowała w roku wysokich opadów regularnymi wzrostami poziomu zwierciadła wody.

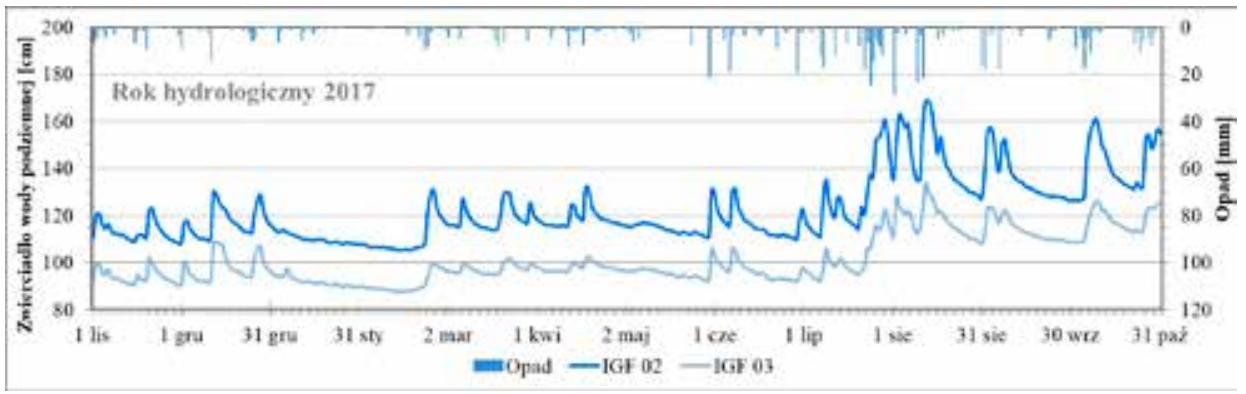

Ryc. 5. Stany wód w piezometrach IGF02 i IGF03 w roku hydrologicznym 2017

Fig. 5. Groundwater levels in the observation wells IGF02 and IGF03 in hydrological year 2017

Rok suchy charakteryzuje się przeciwną tendencją. Wraz z nastaniem cieplejszej pory roku, od przełomu kwietnia i maja, obserwowano regularny spadek poziomu wody w obu piezometrach do $111,8 \mathrm{~cm}$ w IGF02 i 77,0 $\mathrm{cm}$ w IGF03 (ryc. 6).

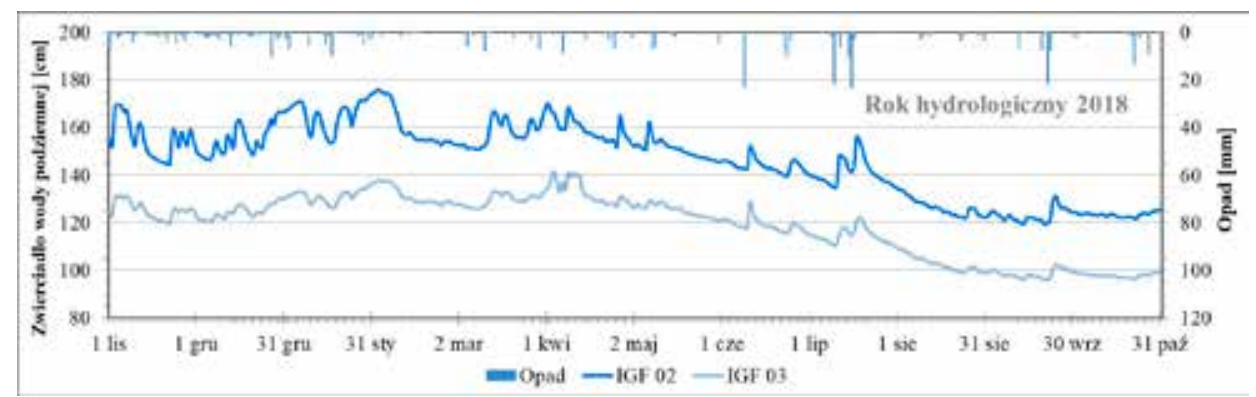

Ryc. 6. Stany wód w piezometrach IGF02 i IGF03 w roku hydrologicznym 2018

Fig. 6. Groundwater levels in the observation wells IGF02 and IGF03 in hydrological year 2018

Należy zaznaczyć, że oba otwory położone są stosunkowo blisko siebie, na lewym brzegu Różanego Strumienia, a wahania zwierciadła wody następują w nich w podobnym czasie, przy czym w przypadku IGF03 są mniej wyraźne niż w IGF02. 


\section{Korelacje opad-natężenie przepływu-stany wód podziemnych}

Czas reakcji zlewni na opad atmosferyczny określono jako czas, dla którego zaobserwowano najwyższą wartość współczynnika korelacji liniowej Pearsona (R). Etapami zmieniano początek zakresu danych dla jednego z dwóch korelowanych parametrów, zgodnie z metodyką opisaną w rozdziale Dane pomiarowe $i$ metodyka badawcza. W tabeli 1 zestawiono wyniki obliczeń współczynnika korelacji opadu oraz natężenia przepływu w Różanym Strumieniu, opadu i stanów wód podziemnych (w piezometrach IGF02 i IGF03), a także natężenia przepływu w badanym cieku i stanów wód podziemnych. Obliczenia wykonano dla każdego miesiąca w obu analizowanych latach hydrologicznych. Przyjęto, że współczynnik korelacji $\mathrm{R}$ w przedziale $0-0,2$ oznacza brak związku korelacyjnego, a w przedziałach: $0,2-0,4 ; 0,4-0,7 ; 0,7-0,9$ i $0,9-1,0$ wskazuje odpowiednio: słaby, średni, silny i bardzo silny związek korelacyjny.

Należy podkreślić, że dla sierpnia 2018 r. nie można było obliczyć korelacji przepływu Różanego Strumienia z opadem oraz ze stanami wód w poszczególnych piezometrach ze względu na wyschnięcie cieku. Dalej korelacja została obliczona po 14 września, a więc od dnia, w którym ponownie zaobserwowano przepływ wody.

\section{Korelacje opadu z natężeniem przepływu oraz stanami wód podziemnych}

W roku bardzo wilgotnym (2017) czas reakcji natężenia przepływu w Różanym Strumieniu na opad atmosferyczny zarówno dla całego roku, jak i dla poszczególnych miesięcy charakteryzował się jednodobowym przesunięciem. Z wyjątkiem stycznia 2017 r. poszczególne współczynniki R wskazywały na średni lub silny związek korelacyjny. Dla roku suchego (2018) w zakresie zarówno całego roku, jak i dla każdego z miesięcy opóźnienie reakcji wyniosło dwie doby. Współczynnik korelacji wskazuje na brak związku w okresie całego roku $(\mathrm{R}=0,159)$, jednakże dla poszczególnych miesięcy korelacje te w większości są średnie lub silne.

Opóźnienie reakcji stanu wód podziemnych w piezometrze IGF02 w roku hydrologicznym bardzo wilgotnym (2017) wynosiło 1 lub 2 doby, z wyjątkiem 4 dób w październiku 2017. W roku tym współczynnik R w styczniu osiągnął minimum, a w maju maksimum. Związki korelacyjne w roku bardzo wilgotnym (2017) są w większości średnie lub silne. W roku suchym (2018) czas reakcji znacznie się wydłużył. $Z$ wyjątkiem maja 2018 wody podziemne reagowały na opad z opóźnieniem dwóch do czterech dób. $Z$ obliczeń przeprowadzonych dla całego roku 2018 wynikają trzydniowe przesunięcie reakcji na opad w piezometrze IGF02, przy braku korelacji $(\mathrm{R}=0,081)$. W poszczególnych miesiącach tego roku odnotowano słabe lub średnie związki korelacyjne. 
Tabela 1. Zestawienie przesunięcia dobowego i współczynnika korelacji reakcji wód powierzchniowych i podziemnych na opady w zlewni Różanego Strumienia w latach hydrologicznych 2017 oraz 2018

Table 1. Lag time (in days) and correlation coefficient values (R) for precipitation, discharge and groundwater levels in the Różany Strumień basin in hydrological years 2017 and 2018

\begin{tabular}{|c|c|c|c|c|c|c|c|c|c|c|}
\hline \multirow[t]{2}{*}{ Okres } & \multicolumn{2}{|c|}{$\begin{array}{c}\text { Opad - natężenie } \\
\text { przepływu }\end{array}$} & \multicolumn{2}{|c|}{$\begin{array}{c}\text { Opad - } \\
\text { stany wód } \\
\text { podziemnych } \\
\text { IGF02 }\end{array}$} & \multicolumn{2}{|c|}{$\begin{array}{c}\text { Opad - } \\
\text { stany wód } \\
\text { podziemnych } \\
\text { IGF03 }\end{array}$} & \multicolumn{2}{|c|}{$\begin{array}{c}\text { Natężenie } \\
\text { przepływu } \\
\text { - stany wód } \\
\text { podziemnych } \\
\text { IGF02 }\end{array}$} & \multicolumn{2}{|c|}{$\begin{array}{c}\text { Natężenie } \\
\text { przepływu } \\
\text { - stany wód } \\
\text { podziemnych } \\
\text { IGF03 }\end{array}$} \\
\hline & $\begin{array}{c}\text { przesu } \\
\text { nięcie } \\
\text { [dni] }\end{array}$ & $\mathrm{R}$ & $\begin{array}{c}\text { przesu } \\
\text { nięcie } \\
\text { [dni] }\end{array}$ & $\mathrm{R}$ & $\begin{array}{c}\text { przesu } \\
\text { nięcie } \\
\text { [dni] }\end{array}$ & $\mathrm{R}$ & $\begin{array}{c}\text { przesu } \\
\text { nięcie } \\
\text { [dni] }\end{array}$ & $\mathrm{R}$ & $\begin{array}{c}\text { przesu } \\
\text { nięcie } \\
\text { [dni] }\end{array}$ & $\mathrm{R}$ \\
\hline Listopad 2016 & 1 & 0,800 & 2 & 0,561 & 1 & 0,591 & 0 & 0,679 & 0 & 0,738 \\
\hline Grudzień 2016 & 1 & 0,698 & 2 & 0,471 & 2 & 0,469 & 0 & 0,799 & 0 & 0,775 \\
\hline Styczeń 2017 & 1 & 0,256 & 2 & 0,336 & 3 & 0,470 & 0 & 0,097 & 2 & 0,132 \\
\hline Luty 2017 & 1 & 0,794 & 2 & 0,655 & 3 & 0,568 & 1 & 0,908 & 1 & 0,887 \\
\hline Marzec 2017 & 1 & 0,676 & 2 & 0,493 & 3 & 0,460 & 0 & 0,713 & 1 & 0,715 \\
\hline Kwiecień 2017 & 1 & 0,807 & 1 & 0,543 & 2 & 0,434 & 0 & 0,852 & 0 & 0,682 \\
\hline Maj 2017 & 1 & 0,739 & 1 & 0,656 & 1 & 0,610 & 0 & 0,926 & 0 & 0,915 \\
\hline Czerwiec 2017 & 1 & 0,978 & 1 & 0,500 & 1 & 0,361 & 0 & 0,518 & 0 & 0,393 \\
\hline Lipiec 2017 & 1 & 0,780 & 1 & 0,485 & 1 & 0,449 & 1 & 0,818 & 1 & 0,788 \\
\hline Sierpień 2017 & 1 & 0,878 & 3 & 0,552 & 3 & 0,535 & 1 & 0,800 & 2 & 0,723 \\
\hline Wrzesień 2017 & 1 & 0,841 & 2 & 0,605 & 2 & 0,553 & 1 & 0,918 & 1 & 0,895 \\
\hline Październik 2017 & 1 & 0,709 & 4 & 0,624 & 5 & 0,610 & 1 & 0,881 & 2 & 0,841 \\
\hline 2017 & 1 & 0,716 & 2 & 0,431 & 2 & 0,326 & 1 & 0,734 & 1 & 0,639 \\
\hline Listopad 2017 & 2 & 0,609 & 2 & 0,370 & 3 & 0,332 & 1 & 0,749 & 1 & 0,739 \\
\hline Grudzień 2017 & 2 & 0,644 & 3 & 0,289 & 3 & 0,240 & 0 & 0,835 & 1 & 0,823 \\
\hline Styczeń 2018 & 2 & 0,567 & 4 & 0,289 & 5 & 0,237 & 1 & 0,839 & 1 & 0,751 \\
\hline Luty 2018 & 2 & 0,217 & 3 & 0,345 & 3 & 0,342 & 2 & 0,717 & 2 & 0,692 \\
\hline Marzec 2018 & 2 & 0,450 & 3 & 0,228 & 5 & 0,260 & 0 & 0,202 & 0 & 0,110 \\
\hline Kwiecień 2018 & 2 & 0,256 & 2 & 0,364 & 5 & 0,180 & 0 & 0,821 & 2 & 0,652 \\
\hline Maj 2018 & 2 & 0,658 & 0 & 0,216 & 3 & 0,215 & 0 & 0,670 & 0 & 0,629 \\
\hline Czerwiec 2018 & 2 & 0,919 & 2 & 0,595 & 2 & 0,599 & 0 & 0,778 & 0 & 0,722 \\
\hline Lipiec 2018 & 2 & 0,934 & 2 & 0,651 & 3 & 0,619 & 0 & 0,814 & 1 & 0,697 \\
\hline Sierpień 2018 & - & - & 3 & $-0,005$ & 4 & $-0,108$ & - & - & - & - \\
\hline Wrzesień 2018 & 2 & 0,854 & 3 & 0,493 & 4 & 0,481 & 0 & 0,832 & 0 & 0,717 \\
\hline Październik 2018 & 2 & 0,354 & 4 & 0,403 & 4 & 0,381 & 1 & 0,456 & 2 & 0,369 \\
\hline 2018 & 2 & 0,159 & 3 & 0,081 & 3 & 0,036 & 1 & 0,82 & 1 & 0,753 \\
\hline
\end{tabular}


Większą zmiennością czasu reakcji w poszczególnych miesiącach charakteryzuje się piezometr IGF03. Dla roku bardzo wilgotnego (2017) opóźnienie reakcji wyniosło dwie doby $(\mathrm{R}=0,326)$, jednakże $\mathrm{w}$ poszczególnych miesiącach wahało się od 1 do 3 dób, z wyjątkiem października 2017 r., kiedy reakcja wystąpiła w 5 dobie. $Z$ kolei w roku suchym (2018) czas reakcji był wydłużony i wynosił 2-5 dób w poszczególnych miesiącach. Dla całego roku 2018 korelacja stanów wód i opadu atmosferycznego wynosiła $\mathrm{R}=0,036$, a maksimum osiągnęła w trzeciej dobie.

W sierpniu 2018 r. z powodu suszy doszło do zaniku przepływu w Różanym Strumieniu, co dla piezometrów IGF02 oraz IGF03 skutkowało ujemną korelacją opadów i stanu wody. Korelacje opadów z natężeniem przepływu w Różanym Strumieniu oraz stanami wody w piezometrach IGF02 i IGF03 w poszczególnych miesiącach lat 2017 i 2018 pokazano na rycinie 7 .

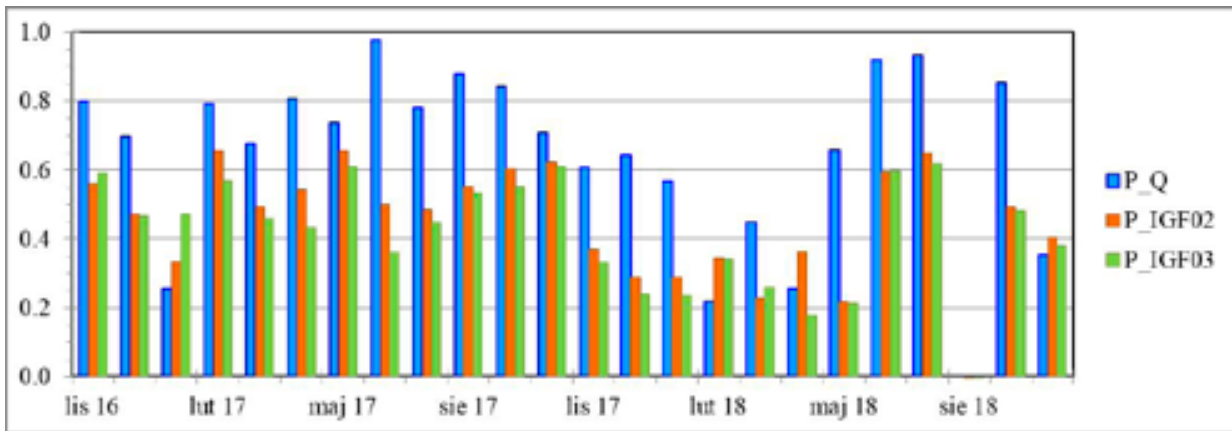

Ryc. 7. Miesięczne korelacje między opadem (P) a natężeniem przepływu (Q) w Różanym Strumieniu oraz stanami wody w piezometrach IGF02 i IGF03

Fig. 7. Monthly correlations between precipitation (P), the water flow rate of the Różany Strumień (Q) and water levels in the observation wells IGF02 and IGF03

\section{Korelacje natężenia przepływu ze stanami wód w podziemnych}

W obu obserwowanych piezometrach zarówno w roku bardzo wilgotnym (2017), jak i suchym (2018) reakcja położenia zwierciadła wody następowała z dobowym przesunięciem względem zmian natężenia przepływu w Różanym Strumieniu. Wartość współczynnika korelacji w większości miesięcy przekraczała 0,6, wskazując na średnie, silne, a w kilku przypadkach bardzo silne związki korelacyjne.

$\mathrm{Z}$ analizy miesięcznych korelacji wynika, że w piezometrze IGF02 reakcja na zmiany natężenia przepływu następowała albo w tej samej dobie (przesunięcie równe 0), albo w dobie następnej (przesunięcie równe 1). Wartości współczynnika R wskazują w większości na średni lub silny związek korelacyjny. Także w przypadku roku suchego (2018) reakcja na zmiany natężenia przepływu 
następowała albo w tej samej dobie, albo w dobie następnej. Współczynnik korelacji, z wyjątkiem marca 2018 r. $(\mathrm{R}=0,202)$ i października 2018 r. $(\mathrm{R}=0,456)$, wynosił więcej niż 0,7 , co świadczy o silnym związku korelacyjnym.

Analiza miesięcznych korelacji w piezometrze IGF03 wskazuje na opóźnienia od 0 do 2 dób. W większości miesięcy są to silne związki korelacyjne $(\mathrm{R}>0,7)$, które rozkładają się podobnie jak w piezometrze IGF02 (ryc. 8).

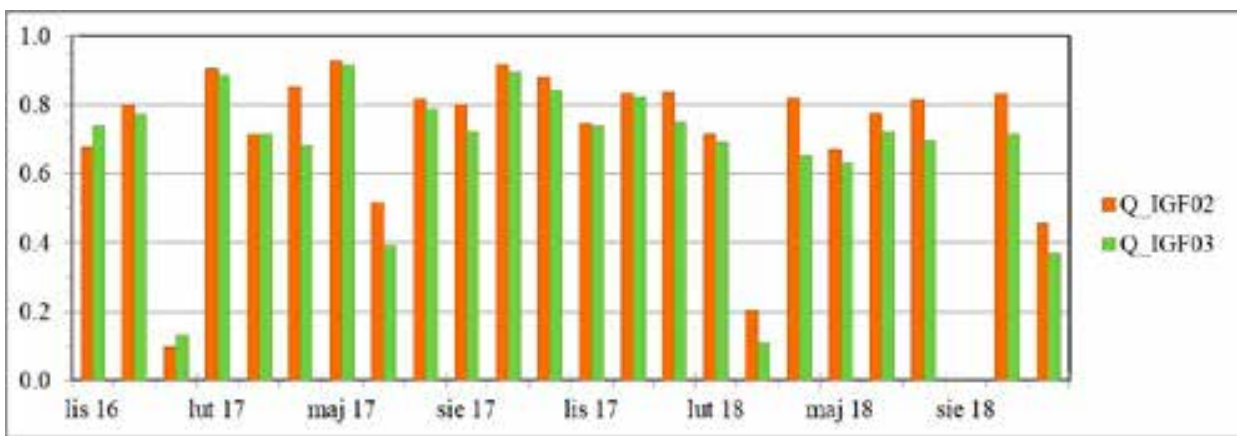

Ryc. 8. Miesięczne korelacje między natężeniem przepływu (Q) w Różanym Strumieniu a stanami wody w piezometrach IGF02 i IGF03

Fig. 8. Monthly correlations between the flow rate of Różany Strumien (Q) and the water levels in the observation wells IGF02 and IGF03

Ponieważ w badanym odcinku Różany Strumień ma charakter infiltracyjny, to należało oczekiwać wysokich korelacji między natężeniem przepływu wody w cieku a stanami wód podziemnych, co potwierdzono przeprowadzonymi obliczeniami.

\section{Zakłócenia związków korelacyjnych przez antropopresję}

Zlewnia Różanego Strumienia jest silnie obciążona antropopresją, która jest przyczyną osłabienia badanych związków korelacyjnych. Na rycinie 8 pokazano, że w miesiącach: styczniu 2017 r., marcu 2018 r. oraz sierpniu 2018 r. nastąpiło wyraźne obniżenie współczynnika korelacji. Przyczyną zakłócenia obiegu wody w badanej zlewni były zrzuty wody ze zbiorników wyrównawczych znajdujących się w górnym biegu cieku. Zbiorniki te są co jakiś czas opróżniane przez zrzutu wody bezpośrednio do Różanego Strumienia. Dwa przykłady zakłóceń przepływu wody z powodu tych zrzutów przedstawiono na rycinie 9 . Anomalia z sierpnia 2018 r. spowodowana była suszą, która doprowadziła do zaniku przepływu w cieku. 
a

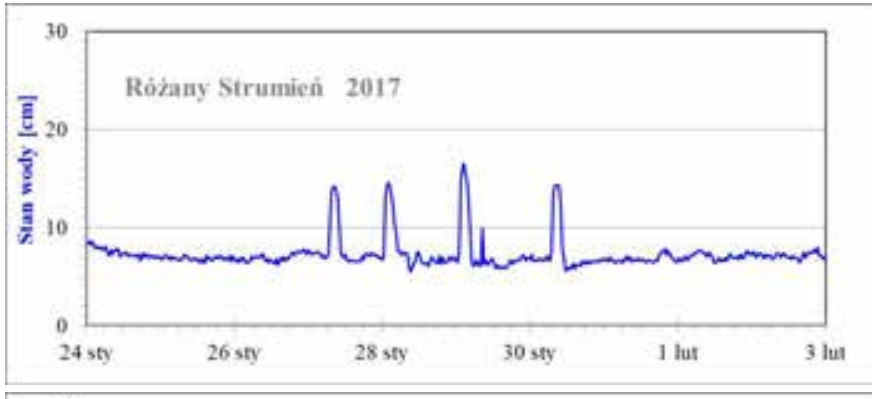

b

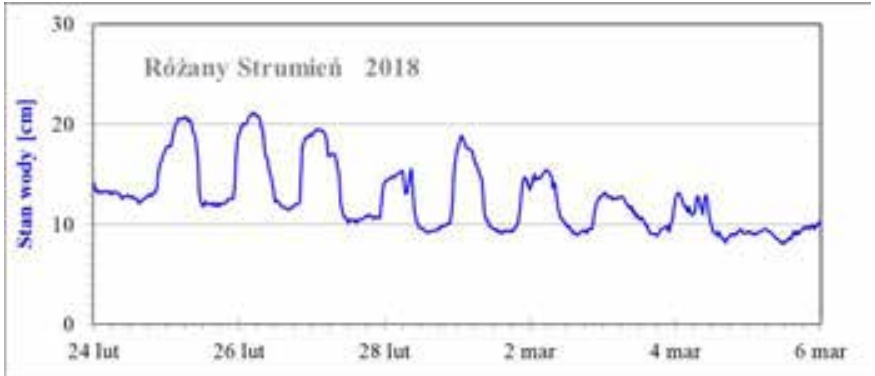

Ryc. 9. Przykłady zakłócenia przepływu wody w Różanym Strumieniu przez zrzuty wody ze zbiorników Aquanetu: a) w styczniu 2017 r., b) na przełomie lutego i marca 2018 r.

Fig. 9. Examples of Różany Strumień flow alterations caused by the discharge of water from the Aquanet reservoirs a) in January 2017, b) in February and March 2018

\section{PODSUMOWANIE I WNIOSKI}

Na podstawie danych dobowych dotyczących wielkości opadu atmosferycznego, natężenia przepływu w Różanym Strumieniu oraz poziomu zwierciadła wody w dwóch piezometrach zlokalizowanych w bezpośrednim otoczeniu strumienia określono wpływ opadu na stany wód powierzchniowych i podziemnych w zlewni Różanego Strumienia. Określono także czas, po którym wody w obrębie zlewni reagują na opad. Do celów badawczych wybrano dane z dwóch lat hydrologicznych: roku bardzo wilgotnego (2017) oraz suchego (2018). W wyniku przeprowadzonych analiz statystycznych stwierdzono wpływ opadów atmosferycznych zarówno na natężenie przepływu Różanego Strumienia, jak i na stany wód podziemnych. Na podstawie obliczonego współczynnika korelacji i siły związku korelacyjnego dla wszystkich analizowanych miesięcy należy stwierdzić, że wpływ opadu na natężenie przepływu Różanego Strumienia jest wyższy niż wpływ opadu na wysokość zwierciadła wód podziemnych w otoczeniu cieku. Wody powierzchniowe szybciej reagują na opad atmosferyczny niż wody podziemne. Analizując wpływ opadu na wody zlewni Różanego Strumienia stwierdzono relatywnie niskie wartości współczynnika korelacji w niektórych miesiącach, zarówno bardzo wilgotnego, jak i suchego roku hydrologicznego. 
Jest to związane $\mathrm{z}$ warunkami atmosferycznymi i glebowo-gruntowymi na obszarze zlewni, a także wyraźną antropopresją. Przykładowo, w miesiącach zimowych opad często występuję w postaci śniegu, ponadto obserwuje się przemarzanie gruntu. Wody powierzchniowe i podziemne są wówczas w mniejszym stopniu i z większym opóźnieniem zasilane opadem. W sierpniu 2018 r. (suchy rok hydrologiczny) również stwierdzono marginalny wpływ opadu na wody podziemne. W miesiącu tym opad był wyjątkowo niski i wynosił 14,8 mm. Większość tego opadu została zretencjonowana w środowisku gruntowym lub w wyniku ewapotranspiracji trafiła ponownie do atmosfery, nie zasilając warstwy wodonośnej. Ponadto w przypadku zmian położenia zwierciadła wód podziemnych na przesunięcia dobowe oraz współczynnik korelacji R istotny wpływ ma odległość badanego piezometru od cieku. Zmiany w piezometrze położonym w większej odległości od Różanego Strumienia (IGF03) są obserwowane po dłuższym czasie aniżeli w piezometrze położonym bliżej (IGF02). Podobnie uzyskiwane wartości współczynnika korelacji są niższe dla otworu zlokalizowanego w większej odległości od cieku.

\section{LITERATURA}

Granato G.E., 2012. Estimating Basin Lagtime and Hydrograph- Timing Indexes Used to Characterize Stormflows for Runoff-Quality Analysis. Scientific Investigations Report 2012-5110. US Geol. Survey, Reston, Virginia.

Graf R., Kajewski I., 2013: Ksztaltowanie się elementów bilansu wodnego w zlewni Mogilnicy na podstawie badań symulacyjnych. Nauk. Przyr. Technol., 7(1), 1-11.

Healy R.W., 2010: Estimating groundwater recharge. Cambridge Univ. Press.

Kaczorowska Z., 1962: Opady w Polsce w przekroju wieloletnim. Przegl. Geogr. IG PAN, 33. Kondracki J., 2009: Geografia regionalna Polski. Wyd. Nauk. PWN, Warszawa.

Krajewski A., Banasik K., 2013: Czas reakcji zlewni zurbanizowanej na opady wywotujace wezbrania. Act. Scientiarum Polonorum. Archit., 12(4), 135-146.

Major M., Chudzińska M., Majewski M., Staszak-Piekarska A., 2016: Stacja Bazowa Zintegrowanego Monitoringu Środowiska Przyrodniczego Różany Strumień (2013), [w:] A. Kostrzewski (red), Stacje naukowe Uniwersytetu im. Adama Mickiewicza w Poznaniu, Wyd. Nauk. UAM, Poznań, 153-180.

McCuen R., Wong S., Rawls W., 1984: Estimating urban time of concentration. J. Hydraul. Eng., 110(7), 887-904.

Okońska M., Wolny F., 2011: Rozpoznanie hydrogeologiczne jako element przygotowań do badań migracji znacznika $w$ warstwie wodonośnej. Biul. PIG, 445, 447-454.

Qi P., Zhang G., Jun Xu Y., Wang L., Ding C., Cheng C., 2018: Assessing the Influence of Precipitation on Shallow Groundwater Table Response Using a Combination of Singular Value Decomposition and Cross-Wavelet Approaches. Water., 10, 598.

Woś A., 1993: Regiony klimatyczne Polski w świetle częstotliwości występowania różnych typów pogody. Zesz. IGiPZ PAN, t. 20, Warszawa. 